with some of the manufacturers of certain articles of food, such as pickles, since others do not use them at all.

The report considers first the different substances which have been used as preservatives and their effect upon the human economy; they can be divided into three groups. In the first are hydrofluoric acid, its salts and derivatives (seldom if ever used at the present time), and formaldehyde and its derivatives. The effects of the latter have been already mentioned in the account of the Committee's Interim Report and will not be further considered here. It is sufficient to state that in the opinion of the Committee, with which we are in complete agreement, the substances in this group should be completely prohibited in articles of diet. In the second group are placed boron preservatives and salicylic acid and its salts: these should also be prohibited. Although this conclusion may cause some surprise, the evidence in favour of it is remarkably strong. In the first place, both boric and salicylic acids act as irritants to the alimentary tract; the former, moreover, is only excreted slowly after absorption, so that its action is cumulative. Boric acid or its salts are used at present very largely in cream, butter, liquid eggs, margarine, and potted meats, or dusted over bacon and hams exported to Great Britain: but since these products are frequently sold without the addition of preservatives, it appears quite possible to dispense with them, providing methods of preparation and conditions of transport are satisfactory. This conclusion is strengthened by the fact that at the present day the milk supply is satisfactorily maintained although the addition of preservatives is forbidden, a state of affairs which, twenty-five years ago, was considered to be impossible of achievement in some quarters. As regards salicylic acid, which is used chiefly in beverages, benzoic acid has about the same effectiveness as a preservative and is less irritant to the stomach, and is therefore preferable.

The third group comprises the least harmful of the preservatives in benzoic acid, sulphurous acid, and their salts: the report gives a list of the foods and beverages in which they may be permitted, together with the maximum amounts allowable. Sulphur dioxide may be permitted in sausages, jam, dried and preserved fruits, beer and cider, and wines, cordials, and fruit juices, in amounts of a few grains per pound or pint. Benzoic acid should be allowed only in the following beverages: coffee extract, nonalcoholic wines and cordials, and sweetened mineral waters and ginger-beer.

Turning to the question of colouring matters, the Committee advises the prohibition of the use of copper sulphate as an agent for preserving the colour of green vegetables. They consider that this will not affect the sale of canned vegetables, seeing that peas canned without the use of copper find a ready sale in Great Britain. As regards other colouring matters, a few pigments containing iron and some natural organic colours such as gamboge, saffron, caramel, and cochineal are considered harmless : but of the synthetic aniline dyes, relatively few have been considered harmless in other countries, and the Committee recommends that a list of those permitted should be drawn up by the Minister of Health: this is necessary, since many of these dyes are potent antiseptics in dilute solutions; moreover, they cannot be grouped in classes, since a harmful product may be closely related to one that is quite innocuous.

Finally, the report considers the best method of making its conclusions effective : among its recommendations here is one that the amount of preservative or nature of colouring matter permitted should be definitely laid down by law, and another that the processes of preparation of food for human consumption should be under closer control. In this connexion, improved methods and facilities of transport and storage are urgently required. In one of the appendices is given an interesting example of the co-operation of a trade in reducing the amount of preservative present in a food, by its members agreeing not to use the article containing it in certain types of foodstuffs prepared by them. The report should do much to raise the standard of preparation of food in Great Britain.

\title{
Works of Early Man in East Anglia.
}

$\mathrm{A}^{\mathrm{T}}$

the autumn meeting of the Prehistoric Society of East Anglia, held at the rooms of the Geological Society, Burlington House, London, on November I2, Mr. R. A. Smith, and afterwards the president, Mr. Henry Balfour, in the chair, special reference was made to the loss sustained through the death of the late Mr. E. T. Lingwood, of Westleton, who, in addition to great abilities and enthusiasm as a practical excavator and collector of flint implements, had for years done very valuable voluntary work by drawing large numbers of the specimens selected for illustration in the annual Proceedings of the Society. Had Mr. Lingwood lived, a proposal to offer him honorary membership of the Society would have been brought forward at the next annual meeting, and it was unanimously resolved by the London meeting that this distinction should be offered to Mrs. Lingwood, together with an expression of the sympathy of the members of the Society.

An important announcement concerning the protection of Grime's Graves, Norfolk, as a national monument was made by the hon. secretary, Mr. G. Maynard, of the Ipswich Museum, who stated that H.M. Office of Works has accepted a suggestion made on behalf of the Society and has taken steps to include in the schedule a considerable area of the open warren which borders the well-known group of ancient flint mines on the Weeting Hall estate. The additional area includes the sites of the recently discovered pits on the slopes of the Grime's Graves ridge which are being investigated by Mr. A. L. Armstrong.

It was also announced that with the approval of the Office of Works, the owner of the estate has given permission for the erection of a shelter over the mouth of the pit cleared out by the Society in I9I4 and subsequent years. This protection is designed to prevent the silting up of the entrance to the galleries at the bottom of the pit, and to facilitate entrance to the old mine workings. The delimitation of a footpath across the warren to the site has also been agreed to. Information as to the probable cost of the shelter is being obtained, and the council of the Society is shortly to be asked to consider the question of taking up the scheme.

Mr. J.P.T. Burchell described some stratified finds on the North Kent coast, where the peculiar elongated flint implement known from its abundance in the bed of the Thames as the "Thames pick," is found in plenty at the foot of the cliffs but is without a definite geological horizon. The cliffs examined are at Bishopstone near Reculver, and Hampton near Herne Bay. At the former site, hand-axes of Chelles and St. Acheul type have been found in the ochreous gravel which is capped by brick earth, with Neolithic flakes and cores in its upper levels.

Sunk in the top of the brick earth and adjoining

NO. 2876 , VOL. I I 4 ] 
a shell-heap with Early Iron Age pottery, a hearth has been found containing flint flakes and a small circular implement. An interesting discovery is that an undisturbed stratum of gravel, 5 inches deep, seals in the Iron Age hearth and midden; and above this is $I \frac{1}{2}$ feet to 4 feet of loam with flints and more pottery and burnt fints to the surface. As the Thames pick can scarcely belong to the Iron Age and is probably later than the drift, the only course is to refer it to the lower part of the brick earth.

Mr. W. H. Cook reported on the discovery of a flint implement working-site of late St. Acheul or early Le Moustier date in the Medway valley. Several thousands of flint artifacts were found lying in heaps covered by brick earth and apparently undisturbed since the mid-Pleistocene period. Excavations in the chalk near Frindsbury opposite Rochester have revealed a chalk slope more than half a mile in length leading down to the alluvial plain of the Medway. On the chalk slope are a series of gravels and brick earths resting at various levels on well-defined platforms or terraces. At 90 feet above the river level and corresponding to the roo-foot terrace of the Thames and Somme are the beds of the ancient Medway, which are of the same Chellean-Le Moustier age. The recent discovery was made in a shallow deposit of dark clayey brick earth probably representing the alluvia of the ancient Ioo-foot terrace river, as it occurs on the upper limits of the terrace and lies in a hollow of an ancient calcareous surface loam which is clearly older than the terrace deposits. In addition to palæolithic hand-axes, scrapers and grattoir, hammerstones, masses of flint flakes and numbers of massive core pieces were found. None of the cores were, however, of the tortoise-backed type. An accumulation of coarse sub-angular fragments of chalk, apparently equivalent to the well-known Coombe rock of Northfleet, etc., was found at the junction of the chalk with the drift beds at various levels, but it is clearly of later age than the roo-foot terrace.

Dr. Cyril Fox, of Cambridge, dealt with evidence of continuity of occupation of a site known as Bellhus, at Abington Pigotts, Cambridge, from Early Iron Age down to late Medieval times. The settlement had probably been founded in La Tene I. times (400250 B.c.), possibly as a result of the general tendency elsewhere exemplified during this Age for migration to take place from the pasture-land to the more fertile districts bordering the alluvium, and thus connected with the early development of corn growing. The evolution of the pottery forms during the Early Iron Age was discussed and many examples shown. The abundance of Ist century A.D. finds seems to show that no serious setback in prosperity accompanied the Roman conquest and the story of the settlement only became obscure after A.D. 390. Certain pottery forms, particularly the Roman mortarium, seem to show an evolution into types which can be clearly distinguished as Early Saxon.

Mr. A. L. Armstrong reported upon the past season's work at Grime's Graves, Norfolk. The continuance of last year's excavations has shown that the simple shaft-pits discovered on the outer slopes of the site are placed close together in rows. The extremely compact nature of the filling and absence of surface indications were again noted, as well as the absence of galleries and deer horn picks. The work appears to have been done with short handpicks of bone. Excavation of a large hearth in one of the old shaft hollows on the higher ground has yielded several examples of pottery now dated as Hallstatt, Early Iron Age.

$$
\text { No. } 2876 \text {, VOL. I I } 4 \text { ] }
$$

\section{University and Educational Intelligence.}

EdInBurgh.-The Prince of Wales visited the University on December 3, for the purpose of opening the new Department of Chemistry, King's Buildings, which has recently been completed at a cost of about $200,000 l$. Immediately afterwards, at a special graduation ceremony in the M'Ewan Hall, the Chancellor of the University, Earl Balfour, conferred on His Royal Highness the honorary degree of LL.D. At the subsequent luncheon, the Principal announced that Sir Alexander Grant had given 5o,oool., that the Carnegie Trust was likely to add I $5,000 l$., and gifts from other sources amounted to ro,oool. which, he stated, would bring relief, encouragement, and hope to those who administer the affairs of the University, though the University's need remained yet so great that he trusted there was a larger harvest to follow.

To commemorate the hundredth anniversary of the foundation of the Royal (Dick) Veterinary College, a Centenary Post-graduate Fellowship has been instituted. A Fellowship Fund has been established, and a deed has recently been signed by which trustees have been appointed to administer the Fund. The aim of the Fellowship is the assistance of promising graduates who may wish to pursue further study and research, and it is hoped that in this way the advancement of veterinary science may be promoted. The amount of the Fund is at present $5802 l$., but the trustees feel confident that additional contributions may be expected from those who benefit from the discoveries of veterinary science, as applied to animal husbandry and public health.

LEEDs.-Applications are invited for two posts, namely, an assistant lectureship in agricultural botany and a demonstratorship in the same subject. Particulars may be obtained from the registrar, to whom applications for the posts should be sent by, at latest, December 22.

LoNDON. - The following doctorates have been conferred :-Ph.D. (Science) : Miss M. A. C. Boas (Lister Institute of Preventive Medicine) for a thesis entitled "Part I. A Method for estimating Calcium and Phosphorus Retention in young growing Rats; Part II. The effect of Green Food in the Diet on the Calcium and Phosphorus Metabolism of Rats as compared with that of Cod Liver Oil "; Amar Nath Puri (Rothamsted Experimental Station) for a thesis entitled "Soil Colloids-A Study of Phenomena relating to Surface Forces in Soil "; Mr. H. Gregory (Imperial College-Royal College of Science) for a thesis entitled "Experimental Determination of the Thermal Conductivities of Gases," and other papers; Mr. E. Spencer (Imperial College-Royal College of Science and University of Liverpool) for a thesis entitled "Investigations of Problems connected with the formation of Authigenous Minerals in Clays, Coals, and Iimestones from India and elsewhere" ; Mr. Murray Stuart, for a thesis entitled "The Potash and Rock Salt Deposits of the Punjab and Kohat "; Mr. G. F. J. Temple (Birkbeck College) for a thesis entitled "Researches in Whitehead's Theory of Relativity," and another paper; Mr. H. G. Turley (Battersea Polytechnic) for a thesis entitled "Experiments on the Walden Inversion. The a-Hydroxy Acids and their Derivatives with special reference to Lactic Acid." Ph.D. (Engineering) : Mr. G. F. Dutton (Imperial College-City and Guilds College) for a thesis entitled "Some Acoustic Properties of Telephones."

Applications are invited for the Keddey FletcherWarr studentships for the promotion of post- 